\title{
RESPONSE TO LACKEY ON “CONDITIONAL PREVENTIVE WAR"
}

Ray Perkins, Jr.

Philosophy / Plymouth State College Plymouth, NH 03264-1600, USA PERKINS@OZ.PLYMOUTH.EDU

I

n "Russell and Preventive War" (Russell, n.s. I4 [1994]: 135-53), I argued that Russell did not advocate unconditional preventive war Lagainst the USSR from I945 to 1947 as some have charged. Rather, he advocated a conditional form according to which the waging of war would be conditioned upon a Soviet refusal to comply, under threat of war, with a Western demand to accede to international controls on armaments. I claimed that this doctrine was less morally offensive than the unconditional version frequently attributed to him, and that the fact that Russell believed that the Soviets would probably comply with such a demandand, therefore, that war would not result-made him less culpable than many of his critics have contended.

In his recent "Reply to Perkins on 'Conditional Preventive War" (n.s. 16 [1996]: 85-8), Professor Douglas Lackey makes essentially two points: (I) that there is no tenable distinction between conditional and unconditional preventive war; and (2) that Russell's belief about the likelihood of war is not morally relevant to the question of his culpability, and will not, therefore, absolve him from blame.

As regards (I), while I agree with Lackey's theoretical position that "all intentional actions have conditions" (p. 86), there is, I should say, a clear moral difference between advocating (say) a bolt-out-of-the-blue preemptive attack on Russia, and Russell's advocacy which carried a lower chance of war and offered hope for avoiding future wars.

As regards (2), I think Lackey may have misunderstood the limited nature of my thesis: I did not claim that Russell was without blame, only that he was less blameworthy than commonly charged. And I think this 
because of the conditional nature of his proposal and because of his belief that it would not, if adopted, have resulted in war. But is Lackey right? Is belief morally irrelevant here?

In a curious analogy Lackey considers the case of Jones, a serial killer, who has resolved to murder the next girl he encounters wearing a pink polka dot dress. His intentions are clearly wicked even if he believes the probability of meeting a girl so dressed is merely five percent. And, says Lackey, Jones is no less culpable than Smith, who has resolved to do a similar thing, but who believes the probability to be ten percent.

I think these examples do show that there are other factors besides the agent's belief in the probability of an action's conditions being met; but I don't think they show that such belief is irrelevant. Consider Robinson (my example) who resolves to do a similar act as Smith and Jones, except that he believes the probability to be 95 percent. Is he not more blameworthy than they just because of his willingness to do what he fully expects to result in evil-especially if they would not have resolved to do such a thing had they believed the probability to be as high as so percent?

The Robinson case is particularly relevant to Russell's situation. As I tried to show, Russell ceased advocating his preventive war proposal when, in the crises of 1948, he came to believe that the Soviets would be unlikely to accede to the ultimatum.

Of course, Lackey is correct to raise the morally relevant question of whether Russell's initial optimism about Soviet compliance was warranted. This is a difficult question which I did not raise in my article, but I do think Russell had good reasons to believe that the Russians would accede: after all, they had been devastated by WWII; their forces were undergoing massive demobilization; and the West, but not they, possessed the atomic bomb, which had already been used with well-known effect against Japan.

Finally, there is much about Lackey's analogy which doesn't do justice to Russell's situation. Russell believed-and not, I think, implausiblythat international controls on atomic weaponry were a necessary and sufficient condition for long-term human survival. It would be as if Jones' resolution were based on a reasonable belief to the effect that a slight risk of doing a murder was necessary for the prevention of a near-certain future massacre. Hitherto, by no small amount of good luck, the world has escaped Russell's worst nightmare. But if Russell was right about the necessity of international controls for the long-term avoidance of selfdestruction, his "wicked" proposal may not only have been forgivable, it may yet be judged to have involved a risk worth taking. 